\title{
Incidence of deep vein thrombosis and quality of venous thromboembolism prophylaxis
}

\section{Incidência de trombose venosa profunda e qualidade da profilaxia para tromboembolismo venoso}

\author{
Alberto Okuhara ${ }^{1}$; Túlo Pinho Navarro²; Ricardo Jayme Procópio 3 ; Rodrigo de Castro Bernardes'4; Leonardo de Campos Correa \\ Oliveira ${ }^{5}$; Mariana Paschoaleti Nishiyama ${ }^{5}$
}

\author{
A
}

\begin{abstract}
Objective: to determine the incidence of deep vein thrombosis and prophylaxis quality in hospitalized patients undergoing vascular and orthopedic surgical procedures. Methods: we evaluated 296 patients, whose incidence of deep venous thrombosis was studied by vascular ultrasonography. Risk factors for venous thrombosis were stratified according the Caprini model. To assess the quality of prophylaxis we compared the adopted measures with the prophylaxis guidelines of the American College of Chest Physicians. Results: the overall incidence of deep venous thrombosis was $7.5 \%$. As for the risk groups, $10.8 \%$ were considered low risk, $14.9 \%$ moderate risk, $24.3 \%$ high risk and $50.5 \%$ very high risk. Prophylaxis of deep venous thrombosis was correct in $57.7 \%$. In groups of high and very high risk, adequate prophylaxis rates were $72.2 \%$ and $71.6 \%$, respectively. Excessive use of chemoprophylaxis was seen in $68.7 \%$ and $61.4 \%$ in the low and moderate-risk groups, respectively. Conclusion: although most patients are deemed to be at high and very high risk for deep vein thrombosis, deficiency in the application of prophylaxis persists in medical practice.
\end{abstract}

Key words: Thromboembolism. Venous thrombosis. Venous thrombosis/prevention and control. Risk factors. Incidence.

\section{INTRODUCTION}

$\mathrm{D}$ eep vein thrombosis (DVT) is a major cause of hospital deaths in the world and, paradoxically, the most preventable ${ }^{1}$. In the United States in 2010 were estimated 900,000 annual cases of thromboembolism and one third of them died. Of the survivors, $4 \%$ developed pulmonary hypertension. It is estimated that $25-50 \%$ of patients with DVT will develop post-thrombotic syndrome, with impaired quality of life?

Although the guidelines for prophylaxis of venous thrombosis exist for over 15 years, they are as yet completely applied in less than $55 \%$ of indications ${ }^{3}$. Accordingly, one in every six cases of thromboembolism could be avoided ${ }^{4}$.

Investigations on the actual situation of each institution would allow to reveal the true incidence of deep venous thrombosis, the profiles of hospitalized patients and the identification of groups at high and very high risk in order to take measures for the correct prophylaxis and therapy against this serious condition according to the best scientific evidence.

The objectives of this study were to determine the incidence of deep venous thrombosis of the lower limbs and quality of drug prophylaxis against venous thromboembolism.

\section{METHODS}

The study was conducted at the Risoleta Tolentino Neves University Hospital, Federal University of Minas Gerais, Belo Horizonte, Minas Gerais State, Brazil. The project received approval from the Research Ethics Committee, under protocol number 231/05 (SISNEP: CAAE 0231.0.203.000-05), in accordance with local regulations and signing of an informed consent form.

A sample of 296 patients would be required for the two goals. Data were collected between March 2011 and July 2012.

Inclusion criteria were: hospitalization in the clinics of Vascular Surgery and Orthopedics; age over 18 years; undergoing surgical procedures; agreement to participate; and agreement to sign the informed consent form.

Exclusion criteria were: pregnancy or puerperium; use of oral anticoagulants in therapeutic doses for more than 48 hours; atered prothrombin time (international

1. Surgery and Ophthalmology Program, Faculty of Medicine, Federal University of Minas Gerais (UFMG); 2. Department of Surgery, Faculty of Medicine, Federal University of Minas Gerais (UFMG); 3. Endovascular Surgery, Clinics Hospital, UFMG; 4. Cardiovascular Surgery, Madre Teresa Hospital and Mater-Dei Hospital, Belo Horizonte, Minas Gerais; 5. Medical School Graduate, UFMG. 
normalized ratio above 1.5), not having been submitted to ultrasonography; extensive wounds in lower limbs that prevented vascular ultrasound; use of cast or splint in the lower limbs; clinical features of pulmonary thromboembolism; previous history of deep venous thrombosis or pulmonary thromboembolism; and contraindication to pharmacological prophylaxis, such as intracranial hemorrhage, gastroduodenal ulcer activity and blood dyscrasias.

Descriptive analysis was shown in contingency tables with demographic data, admission diagnosis, distribution of risk factors for DVT, type of surgical procedures, type of drug prophylaxis and result of vascular ultrasonography.

Data from medical records, evolutions and prescriptions were computerized.

Prophylaxis against deep vein thrombosis

The prophylaxis protocol considered appropriate in the present study was the guidelines of the American College of Chest Physicians, seventh and eighth editions ${ }^{5,6}$.

Patients considered at low risk need not routinely drug prophylaxis. For moderate risk, the guidelines suggest the use of unfractionated heparin, $5000 \mathrm{IU}$ b.i.d., or low molecular weight heparin, up to $3400 \mathrm{UI}$ q.d. Those considered of high and very high risk should receive unfractionated heparin, $5000 \mathrm{IU}$ t.i.d, or low molecular weight heparin, over 3400 UI q.d.

\section{Statistical Analysis}

The $t$ test was used to assess equality of means according to each objective to be studied. Logistic regression was used to analyze the incidence of venous thrombosis according to admission diagnoses and to made it possible to evaluate the association between DVT and risk factors.
We used the chi square test to assess the difference in the occurrence of DVT between the groups of Vascular Surgery and Orthopedics, the association between venous thrombosis and demographics and the influence of drug prophylaxis on the incidence of DVT.

\section{RESULTS}

The total sample comprised 335 patients. Of then, 94 patients were from Orthopaedics, and 241, from Vascular Surgery. We excluded 39 patients, all belonging to the group of Vascular Surgery, 202 remaining in the latter, resulting in a total of 296 analyzed patients.

Regarding the distribution of sex, 98 (33.3\%) were women and $198(66.6 \%)$ men. The mean age was 57.7 years and the mean body mass index was $24.6 \mathrm{~kg} / \mathrm{m}^{2}$. The admission diagnoses are shown in table 1.

Regarding risk stratification for DVT, 220 patients were considered of high and very high risk for deep venous thrombosis (Table 2). The overall incidence of DVT was $7.5 \%$ (22 patients). Among the Orthopaedics' patients, the incidence was $5.3 \%$ (five patients) and among the Vascular Surgery ones, $8.5 \%$ (17 patients).

The chi-square test did not demonstrate significant differences in the incidence DVT between the two clinics $(p=0.34)$.

The distribution of prophylactic medication is shown in Table 3. Tables 4, 5 and 6 present the evaluation of prophylaxis according risk groups in Global, Vascular Surgery and Orthopedics groups, respectively. In the global context, prophylaxis was considered adequate in 171 patients $(57.7 \%)$. The rates of adequate prophylaxis in the groups Vascular Surgery and Orthopedics were 107 (52.9\%) and $64(68.0 \%)$, respectively.

Table 1 - Admission diagnosis of groups in Vascular Surgery and Orthopedics.

\begin{tabular}{lrc}
\hline Diagnosis & $\mathrm{N}$ & $\%$ \\
\hline Lower Limb Trauma & 101 & 34.2 \\
Peripheral Arterial Disease - Critical Ischemia & 80 & 26.7 \\
Diabetic Foot Infection & 60 & 20.3 \\
Acute Arterial Ischemia & 14 & 4.7 \\
Other (Arthrosis and Arthritis of Knee, Soft Tissue Infections of the Lower Limbs) & 14 & 4.7 \\
Diabetic Foot Sepsis & 13 & 4.4 \\
Aortic Disease & 6 & 2.0 \\
Peripheral Aneurysm & 4 & 1.3 \\
Diabetic Foot and ABI <0.9 & 1 & 0.3 \\
Peripheral Arterial Disease - Asymptomatic / Claudication & 1 & 0.3 \\
Cerebrovascular Disease (Stroke / TIA) & 2 & 0.6 \\
Total & 296 & 100
\end{tabular}

ABI: ankle-brachial index;; TIA: transient ischemic attack 
Table 2 - Distribution of patients according to risk factors.

\begin{tabular}{lrrr}
\hline Groups of risk factors & Vascular Surgery & Orthopedics & Global \\
\hline Low & $17(8.4 \%)$ & $15(16.0 \%)$ & $32(10.8 \%)$ \\
Moderate & $35(27.3 \%)$ & $9(9.6 \%)$ & $44(14.9 \%)$ \\
High & $60(29.7 \%)$ & $12(12.8 \%)$ & $72(24.3 \%)$ \\
Very high & $90(44.6 \%)$ & $58(61.7 \%)$ & 148 \\
Total & 202 & 94 & $290)$ \\
\hline
\end{tabular}

Table 3 - Drug Prophylaxis.

\begin{tabular}{|c|c|c|c|c|}
\hline Drug Prophylaxis & Vascular Surgery & Orthopedics & & Geral \\
\hline Enoxaparin 40mg/day & $130(64.4 \%)$ & $68(72.3 \%)$ & 198 & $(68.9 \%)$ \\
\hline None & $50(25.1 \%)$ & $22(23.4 \%)$ & 72 & $(24.3 \%)$ \\
\hline Enoxaparin 20mg/day & $13 \quad(6.0 \%)$ & $2 \quad(2.1 \%)$ & 15 & $(5.0 \%)$ \\
\hline Enoxaparin 60mg/day & $8 \quad(4 \%)$ & $(1.1 \%)$ & 9 & (3.0\%) \\
\hline
\end{tabular}

Table 4 - Quality of prophylaxis according to groups of risk factors: Vascular Surgery and Orthopedics groups.

\begin{tabular}{|c|c|c|c|c|}
\hline Groups of risk factors & $\begin{array}{c}\text { Inadequate } \\
\text { lower dose } \mathrm{N}(\%)\end{array}$ & $\begin{array}{l}\text { Inadequate } \\
\text { higher dose } \mathrm{N}(\%)\end{array}$ & $\begin{array}{c}\text { Adequate } \\
\mathrm{N}(\%)\end{array}$ & $\begin{array}{c}\text { Total } \\
\mathrm{N}\end{array}$ \\
\hline Low & $0 \quad(0 \%)$ & $22(68.7 \%)$ & $10(31.3 \%)$ & 32 \\
\hline Moderate & $14(31.8 \%)$ & $27(61.4 \%)$ & $3(6.8 \%)$ & 44 \\
\hline High & $20(27.8 \%)$ & $0 \quad(0 \%)$ & $52(72.2 \%)$ & 72 \\
\hline Very high & $42(28.4 \%)$ & $(0 \%)$ & $106(71.6 \%)$ & 148 \\
\hline Total & 76 & 49 & 171 & 296 \\
\hline
\end{tabular}

Table 5 - Quality of prophylaxis according to groups of risk factors: Vascular Surgery group.

\begin{tabular}{|c|c|c|c|c|}
\hline Groups of risk factors & $\begin{array}{c}\text { Inadequate } \\
\text { lower dose } \mathrm{N}(\%)\end{array}$ & $\begin{array}{c}\text { Inadequate } \\
\text { higher dose } \mathrm{N}(\%)\end{array}$ & $\begin{array}{c}\text { Adequate } \\
\mathrm{N}(\%)\end{array}$ & $\begin{array}{c}\text { Total } \\
\mathrm{N}\end{array}$ \\
\hline Low & - & $13(76.5 \%)$ & $4(23.5 \%)$ & 17 \\
\hline Moderate & $8(22.8 \%)$ & $24(68.5 \%)$ & $3(8.5 \%)$ & 35 \\
\hline High & $17(28.2 \%)$ & - & $43(71.8 \%)$ & 60 \\
\hline Very high & $33(36.7 \%)$ & - & $57(63.3 \%)$ & 90 \\
\hline Total & 58 & 37 & 107 & 202 \\
\hline
\end{tabular}

Table 6 - Quality of prophylaxis according to groups of risk factors: Orthopedics group.

\begin{tabular}{|c|c|c|c|c|}
\hline Groups of risk factors & $\begin{array}{l}\text { Inadequate } \\
\text { lower dose } \mathrm{N}(\%)\end{array}$ & $\begin{array}{c}\text { Inadequate } \\
\text { higher dose } \mathrm{N}(\%)\end{array}$ & $\begin{array}{c}\text { Adequate } \\
\mathrm{N}(\%)\end{array}$ & $\begin{array}{c}\text { Total } \\
\mathrm{N}\end{array}$ \\
\hline Baixo & - & $9 \quad(60,0 \%)$ & $6 \quad(40,0 \%)$ & 15 \\
\hline Moderado & $(66,6 \%)$ & $3 \quad(33,3 \%)$ & $0 \quad(0 \%)$ & 9 \\
\hline Alto & $3 \quad(25,0 \%)$ & - & $9 \quad(75,0 \%)$ & 12 \\
\hline Altíssimo & $(15,4 \%)$ & - & $49 \quad(84,4 \%)$ & 58 \\
\hline Total N & 18 & 12 & 64 & 94 \\
\hline
\end{tabular}




\section{DISCUSSION}

The true incidence of deep venous thrombosis in Vascular Surgery patients is little known and has variable rates, from 1.7 to $30 \%$, being related to the diversity of surgical procedures, from minimally invasive ones to major surgeries ${ }^{7-13}$.

As for Orthopaedics, the incidence rate and methods for prophylaxis of venous thrombosis are best known. The rates of DVT in the absence of prophylaxis are between 40 and $60 \%{ }^{5}$ and $2-5 \%$ in its presence ${ }^{14}$.

In this study, the incidence of DVT was similar to the aforementioned studies. One must consider that performing vascular ultrasound in active search of asymptomatic patients could lead to a greater number of diagnoses of venous thrombosis. Perhaps, the quality of instituted prophylaxis in patients with high and very high risk, being superior to publications, may influence the results.

The types of vascular surgical procedures may influence the incidence of DVT. In the Vascular Surgery group, only $3 \%$ were submitted to procedures in the aorta. Moreover, 39\% of the causes of hospitalization for critical ischemia were being largely treated by minimally invasive endovascular revascularization procedures.

\section{Quality of prophylaxis}

Prophylaxis against DVT depends on the presence of risk factors and types of surgical procedures. Adequate prophylaxis grants more protection to the patient and less risk of bleeding events from the use of anticoagulants as well as preventing deaths ${ }^{15-17}$.

Despite the existence of several protocols for the assessment of risk factors and prevention of DVT in medical practice, rates of adherence to these protocols are from 16 to $55 \%{ }^{3,18-24}$.
The results of the present study were similar to the literature, and obtained significant proportion of hospitalized patients considered at high and very high risk, also showing the failure of the implementation of prophylaxis, as only $57.7 \%$ of patients received appropriate prophylaxis protocols.

Additionally, the study showed excessive use of pharmacological prophylaxis in patients at low to moderate risk, in agreement with the literature ${ }^{18,24,25}$

Moreover, in patients exposed to more venous thromboembolic events, the quality of prophylaxis was higher than in the cited studies. The most plausible explanation for this may be the overestimation of risk factors by physicians, considering them routinely and automatically with high and very high risk.

Our findings allow to infer that the overuse of chemoprophylaxis also led to the decline in the quality of drug prophylaxis. One should also stress that the overuse of chemoprophylaxis is associated with greater hospital costs.

Regarding the medications used as prophylaxis, these results indicate agreement with the guidelines $5,26,27$. Enoxaparin was the mainly used anticoagulant, prescribed to $75 \%$ of patients.

There was no association between chemoprophylaxis and incidence of thrombosis $(p=0.199)$. Nionetheless, one must consider that only the use of prophylactic medication or not was evaluated.

From this, the institutions could develop surveillance committees of thromboembolic events that adopt effective strategies to improve the technical knowledge and adherence to adequate prophylaxis protocols in daily medical practice.

In conclusion, although the majority of patients is considered at high and very high risk for deep vein thrombosis in medical practice, there is still a deficiency in the application of prophylaxis.

\title{
R E S U M O
}

\begin{abstract}
Objetivo: determinar incidência de trombose venosa profunda e qualidade de profilaxia em pacientes internados submetidos a procedimentos cirúrgicos vasculares e ortopédicos. Métodos: avaliou-se 296 pacientes, cuja incidência de trombose venosa profunda foi estudada por meio de ultrassonografia vascular. Os fatores de risco para trombose venosa foram estratificados conforme modelo de Caprini. Para avaliação da qualidade de profilaxia comparou-se as medidas adotadas com as diretrizes de profilaxia do American College of Chest Physicians. Resultados: a incidência global de trombose venosa profunda foi 7,5\%. Quanto aos grupos de riscos, 10,8\% foram considerados de baixo risco, 14,9\% moderado risco, 24,3\% alto risco e 50,5\% altíssimo risco. A profilaxia para trombose venosa profunda foi correta em $57,7 \%$. Nos grupos de alto e altíssimo risco, as taxas de profilaxia adequada foram de $72,2 \%$ e $71,6 \%$, respectivamente. O uso excessivo de profilaxia medicamentosa foi evidenciado em $68,7 \%$ e $61,4 \%$ nos grupos de baixo e moderado risco, respectivamente. Conclusão: Embora a maior parte dos pacientes seja considerada de alto e altíssimo risco para trombose venosa profunda, na prática médica persiste a deficiência na aplicação desta profilaxia.
\end{abstract}

Descritores: Tromboembolia. Trombose venosa. Trombose venosa/prenvenção e controle. Fatores de risco. Incidência.

\section{REFERENCES}

1. Geerts WH, Bergqvist D, Pineo GF, Heit JA, Samama CM, Lassen $M R$, et al. Prevention of venous thromboembolism: American
College of Chest Physicians Evidence-Based Clinical Practice Guidelines (8th edition). Chest. 2008;133(6 Suppl):381S-453S. 
2. Kahn SR, Hirsch A, Shrier I. Effect of postthrombotic syndrome on health-related quality of life after deep venous thrombosis. Arch Intern Med. 2002;162(10):1144-8.

3. Caprini JA, Tapson VF, Hyers TM, Waldo AL, Wittkowsky AK, Friedman $R$, et al. Treatment of venous thromboembolism: adherence to guidelines and impact of physician knowledge, attitudes, and beliefs. J Vasc Surg. 2005;42(4):726-33.

4. Arnold DM, Kahn SR, Shrier I. Missed opportunities for prevention of venous thromboembolism: an evaluation of the use of thromboprophylaxis guidelines. Chest. 2001;120(6):1964-71.

5. Geerts WH, Pineo GF, Heit JA, Bergqvist D, Lassen MR, Colwell $C W$, et al. Prevention of venous thromboembolism: the Seventh ACCP Conference on Antithrombotic and Thrombolytic Therapy. Chest. 2004;126(3 Suppl):338S-400S

6. Hirsch J, Guyatt G, Albers GW, Harrington R, Schünemann HJ; American College of Chest Physicians. Executive summary: American College of Chest Physicians Evidence-Based Clinical Practice Guidelines (8th edition). Chest. 2008;133(6 Suppl):71S109S. Erratum in: Chest. 2008;134(4):892.

7. Hamer JD. Investigation of edema of the lower limb following successful femoropopliteal by-pass surgery: the role of phlebography in demonstrating venous thrombosis. Br J Surg. 1972;59(12):979-82.

8. Fletcher JP, Batiste P. Incidence of deep vein thrombosis following vascular surgery. Int Angiol. 1997;16(1):65-8.

9. Hollyoak M, Woodruff P, Muller M, Daunt N, Weir P. Deep venous thrombosis in postoperative vascular surgical patients: a frequent finding without prophylaxis. J Vasc Surg. 2001;34(4):656-60.

10. Farkas JC, Chapuis C, Combe S, Silsiguen M, Marzelle J, Laurian C, et al. A randomised controlled trial of a low-molecular-weight heparin (Enoxaparin) to prevent deep-vein thrombosis in patients undergoing vascular surgery. Eur J Vasc Surg. 1993;7(5):554-60.

11. Angelides NS, Nicolaides AN, Fernandes J, Gordon-Smith I, Bowers $\mathrm{R}$, Lewis JD. Deep venous thrombosis in patients having aorto-iliac reconstruction. Br J Surg. 1977; 64(7):517-8

12. Belch JJ, Lowe GD, Pollock JG, Forbes CD, Prentice CR. Low dose heparin in the prevention of deep-vein thrombosis after aortic bifurcation graft surgery. Thromb Haemost. 1980;42(5):1429-33.

13. Cass AJ, Jennings SA, Greenhalgh RM. Leg swelling after aortic surgery. Int Angiol. 1986:5(3):207-8.

14. White RH, Romano PS, Zhou H. A population-based comparison of the 3-month incidence of thromboembolism after major elective/ urgent surgeries. Thromb Haemost. 2001;86:2255. (Abstract)

15. Collins R, Scrimgeour A, Yusuf S, Peto R. Reduction in fatal pulmonary embolism and venous thrombosis by perioperative administration of subcutaneous heparin. Overview of results of randomized trials in general, orthopedic, and urologic surgery. N Engl J Med. 1988;318(18):1162-73

16. Halkin H, Goldberg J, Modan M, Modan B. Reduction of mortality in general medical in-patients by low-dose heparin prophylaxis. Ann Intern Med.1982;96(5):561-5.

17. Kucher N, Koo S, Quiroz R, Cooper JM, Paterno MD, Soukonnikov $B$, et al. Electronic alerts to prevent venous thromboembolism among hospitalized patients. N Engl J Med. 2005;352(10):969-77.

18. Chopard P, Dörffler-Melly J, Hess U, Wuillemin WA, Hayoz D, Gallino $A$, et al. Venous thromboembolism prophylaxis in acutely ill medical patients: definite need for improvement. J Intern Med. 2005;257(4):352-7
19. Stinnett JM, Pendleton R, Skordos L, Wheeler M, Rodgers GM. Venous thromboembolism prophylaxis in medically ill patients and the development of strategies to improve prophylaxis rates. Am J Hematol. 2005;78(3):167-72.

20. Yu HT, Dylan ML, Lin J, Dubois RW. Hospitals' compliance with prophylaxis guidelines for venous thromboembolism. Am J Health Syst Pharm. 2007;64(1):69-76.

21. Kahn SR, Panju A, Geerts W, Pineo GF, Desjardins L, Turpie AG, et al. Multicenter evaluation of the use of venous thromboembolism prophylaxis in acutely ill medical patients in Canada. Thromb Res. 2007;119(2):145-55.

22. Awidi A, Obeidat N, Magablah A, Bsoul N. Risk stratification for venous thromboembolism in hospitalized patients in a developing country: a prospective study. J Thromb Thrombolysis. 2009;28(3):309-13.

23. Tapson VF, Decousus H, Pini M, Chong BH, Froehlich JB, Monreal $M$, et al. Venous thromboembolism prophylaxis in acutely ill hospitalized medical patients: findings from the International Medical Prevention Registry on Venous Thromboembolism. Chest. 2007;132(3):936-45.

24. Cohen AT, Tapson VF, Bergmann JF, Goldhaber SZ, Kakkar AK, Deslandes $B$, et al. Venous thromboembolism risk and prophylaxis in the acute hospital care setting (ENDORSE study): a multinational cross-sectional study. Lancet. 2008;371(9610):387-94.

25. Deheinzelin D, Braga AL, Martins LC, Martins MA, Hernandez A, Yoshida WB, et al. Incorrect use of thromboprophylaxis for venous thromboembolism in medical and surgical patients: results of a multicentric, observational and cross-sectional study in Brazil. J Thromb Haemost. 2006;4(6):1266-70.

26. Bergqvist D, Burmark US, Flordal PA, Frisell J, Hallböök T, Hedberg $M$, et al. Low molecular weight heparin started before surgery as prophylaxis against deep vein thrombosis: 2500 versus 5000 Xal units in 2070 patients. Br J Surg. 1995;82(4):496-501.

27. Mismetti P, Laporte S, Darmon JY, Buchmüller A, Decousus $\mathrm{H}$. Meta-analysis of low molecular weight heparin in the prevention of venous thromboembolism in general surgery. Br J Surg. 2001;88(7):913-30.

Received on 03/11/2012

Accepted for publication 28/12/2012

Conflict of interest: none.

Source of funding: none.

How to cite this article

Okuhara A, Navarro TP, Procópio RJ, Bernardes RC, Oliveira LCC, Nishiyama MP. Incidência de trombose venosa profunda e qualidade da profilaxia para tromboelmbolismo venoso. Rev Col Bras Cir. [periódico na Internet] 2014;41(1). Disponível em URL: http://www.scielo.br/ rcbc

Address for correspondence:

Alberto Okuhara

E-mail: alberto.hara@yahoo.com.br 